\title{
Comparative archaeometric characterization of recent and historical oak (Quercus spp.) wood
}

\author{
Amir Ghavidel ${ }^{1}$ (D) - Tamás Hofmann ${ }^{2}$ - Miklós Bak ${ }^{3}$ (D) Ion Sandu ${ }^{4}$. \\ Viorica Vasilache ${ }^{4} \mathbb{D}$
}

Received: 29 October 2019 / Published online: 9 July 2020

(c) The Author(s) 2020

\begin{abstract}
The present paper studied the chemical composition of recent and historical oak wood comparing the extractive, holocellulose, $\alpha$-cellulose, lignin, and ash contents. Comprehensive knowledge of the chemical components in recent and historical oak wood will facilitate the use of conservation agent in the restoration and conservation process of the investigated artifacts. The cyclohexane-ethanol extract of historical oak wood was significantly lower compared to recent wood, which can be explained by the leaching of extractives into the soil. No significant differences in the holocellulose and $\alpha$-cellulose content of recent and historical oak wood were found. The lignin and the ash contents were significantly higher in the historical samples. The EDX analysis of the ash of historical oak wood showed remarkably higher iron content compared to the recent material. The result indicated the degradation of hemicelluloses in the historical sample. The significant difference in the amount of ash between the samples was explained by sediment materials that have been introduced into the wood from the soil. SEM imaging made these materials clearly visible as depositions in the cell lumens.
\end{abstract}

\section{Introduction}

Throughout history, people have utilized wood as a base material in everything from art to construction. The remarkable improvement in material processing technologies that occurred in Europe from $6000 \mathrm{BC}$ to $4000 \mathrm{BC}$ represents a turning point in human civilization. A total of 151 oak timbers dating from $5469 \mathrm{BC}$ to $5098 \mathrm{BC}$ were discovered in a waterlogged area in Germany. The wood displayed signs of surprisingly advanced carpentry skills. The recently discovered water wells provide a thorough insight into the earliest wood architecture and the technical capabilities that existed 7000 years ago (Tegel et al. 2012). Further important historical artifacts

Miklós Bak

bak.miklos@uni-sopron.hu

Extended author information available on the last page of the article 
from oak wood found in Europe are the Viking ships that were buried in Gokstad and Oseberg, Norway in the ninth century and later discovered in 1962 (Logan 2003; Richards 2005). The four fourth-century coffins originating from the reign of Valens and Valentinian discovered in the necropolis of Niculitel (Romania) in 1971 are considered the oldest known oak artifacts found on Romanian territory (Sandu et al. 2007; Vasilache et al. 2008).

Being an organic material, wood has low resistance against environmental effects and is also affected by the time of exposure to microbiological and anthropogenic factors. Wood fossilization begins when wood material is submerged under water or buried in soil. This process happens in the absence of oxygen. Wood petrification depends on the characteristics of such an anaerobic environmental condition (Christiernin et al. 2009). Long-term deposition in water or soil determines the rates and mechanisms of degradation. As the conditions might vary from site to site, chemical changes in the material tend to vary. Thus, the chemical composition of archaeological or historic wood material is diverse. Among the conditions, time plays a secondary role in the degradation process (Krutul and Kocoń 1982; Passialis 1997). Several studies have investigated the modification of chemical structure during longterm soil contact and connected changes in the physical and mechanical properties of archaeological or subfossil oak wood. The findings indicate lower cellulose content and higher lignin content in fossil oak wood relative to recent wood. The proportion of lignin increased at the expense of polysaccharides, which are more sensitive to degradation and loss, especially in waterlogged conditions (Krutul et al. 2010; Łucejko et al. 2012; Bader et al. 2013; Kolář et al. 2014; Capano et al. 2015; Baar et al. 2019; Moosavinejad et al. 2019). The disappearance of acetyl side chains and the cleavage of backbones in hemicelluloses are the main chemical alterations of waterlogged cell wall components in wood material. The depolymerization of amorphous cellulose was also observed. In addition, the modification of functional groups and the partial depletion of $\beta-O-4$ links in lignin characterize the changes. (Guo et al. 2019; Walsh-Korb and Avérous 2019) Furthermore, the degradation of cell wall components of waterlogged or buried wood results in increased porosity (higher amount of mesopores in the cell walls) and decreased cellulose crystallinity (Svedström et al. 2012; Broda and Popescu 2019; Han et al. 2020).

In addition to the degradation of the cell wall macromolecules, the deposition of inorganic substances during fossilization also occurs. This process is highly dependent on the subsurface environment. Fossilization can occur as silicification, carbonization, or calcification (Fengel and Wegener 1989; Florian 1990; Fengel 1991; Carrión 2003). The deposition of inorganic substances during long-term soil contact results in higher proportions of ash, calcium, and iron in subfossil wood, though the proportion of potassium was lower in fossil wood (Krutul et al. 2010; Kolár et al. 2014). The variations in chemical composition cause inconsistencies in wood behavior. Mańkowski et al. (2016) found that wood lying in a wet environment for several years turns black as a consequence of the reaction with iron compounds. They also discovered an essential and direct relationship between the ash content in the archaeological oak wood and the density and compressive strength along the fibers. The changes in the chemical composition of historical wood cause increased shrinkage and decreased mechanical properties. The influence of the environment during 
deposition on the changes in chemical composition and mechanical properties is more important than the effect of time (Kolář et al. 2014).

Historical oak wood has been found in various archaeological sites, usually in conditions that are more or less humid. In order to set up a custom conservation plan, the wooden artifacts must be registered and examined after excavation. Bacteria, and sometimes even fungi, may have degraded the wood, but these processes are not yet well understood. Due to the particular circumstances of each excavation project, a wide range of storage conditions must be considered. For particularly long storage periods, it would be advantageous to be able to track whether there is potential for wood deterioration and, if there is, to what degree (Gelbrich et al. 2008). After excavation, preventive preservation, and cleaning, it is recommended to perform scientific investigations on the material in order to prepare it for consolidation, preservation, and restoration. This has two main aims - the first is clarifying the attributes of authentication, and the second is to determine the conservation status. In both cases, it is vital to clear the chemical composition and to identify the species and the age of the wood along with the evaluation of the historical contexts. The latter requires the study of some archaeometric characteristics, respectively, the identification of chemometric quantities with archaeometric value (Fengel 1991; Millard 2002; Pournou 2008; Manning and Kromer 2011; Todaro et al. 2012; Scharnweber et al. 2015; Sen et al. 2016; Luimes et al. 2018).

This study aims to investigate changes in the chemical compounds of oak wood originating from the fourteenth century found in Iasi (Romania) and to compare these with recent wood using different analytical approaches. The most important aspect of the investigated poles is that they served as fences for over 100 years in a pavement. A special load of the material was the presence of urine and waste from the horses used in public transport. After the pavements were destroyed, these poles remained under wet soil conditions for more than 200 years. Such samples have resisted severe conditions in the wet ground for around 400-500 years; hence, their conservation status is little affected. For this reason, the paper presents a comparative study of the chemical composition, the residual ash after burning, the micromorphology by SEM imaging, and the EDX analysis for recent and selected historical oak wood samples (Quercus spp.) in order to determine and compare archaeometric characteristics.

\section{Materials and methods}

\section{Raw materials and preparation}

The recent oak wood samples (Quercus spp.) (SR) originated from a sawmill. These samples are comprised of boards with the dimensions of $45 \times 90 \times 4000 \mathrm{~mm}$ (thickness $\times$ width $\times$ length) representing the most relevant forest growth regions of Suceava, Romania. The samples were cut from heartwood. Defect-free samples (without knots, cracks, or reaction wood and annual growth ring slope $<5^{\circ}$ ) were selected for the tests. 
The investigated historical oak wood ( $\mathrm{SH}$ ) samples were originally used in street pavements as fences in the old urban center of Iasi, Romania. After excavating an archaeological site on Armenia Street (called "Ulita Mate" in the fourteenth century) in downtown Iasi, large columns of oak originating from the fourteenth century were extracted. These poles were about $1 \mathrm{~m}$ long with sharp pointed ends. The excavations were conducted in May-September 2009 when a large amount of archaeological wood was brought to the ARHEOINVEST laboratory (Iasi, Romania) for dendrochronological research and other scientific investigations. The conservation status of the wood was precarious, but fragments with good conservation status of the anatomical elements could be separated and cut crosswise. The wood was black because it had been buried in the soil for a long time (Fig. 1). Nevertheless, the wood's structure remained intact; however, microscopic analysis revealed that most of the lumens of SH sample were filled with foreign matter (depositions).

Wood samples were chipped and dried in an oven at $105 \pm 3{ }^{\circ} \mathrm{C}$. The dried samples were then ground to a powder and sieved. The $250-425 \mu \mathrm{m}$ fraction was used for all chemical analyses.

\section{Analysis and evaluation methods}

\section{Moisture content}

An Ohaus MB-23 moisture analyzer was used to determine the moisture content of the samples as part of all the chemical analyses.

\section{Cyclohexane-ethanol extract}

Samples in the amount of 2-3 g were deposited into covered extraction thimbles and extracted with $100 \mathrm{~mL}$ cyclohexane: ethanol 50:50 v/v solution in a Soxhlet apparatus for $24 \mathrm{~h}$. After extraction, the extract was filled up into a volumetric flask to $100 \mathrm{~mL}$ with pure solvent (ethanol, 99.99\%). From these precisely filled up solutions, $20 \mathrm{~mL}$ was pipetted to a plastic tray and left to dry at room temperature. The

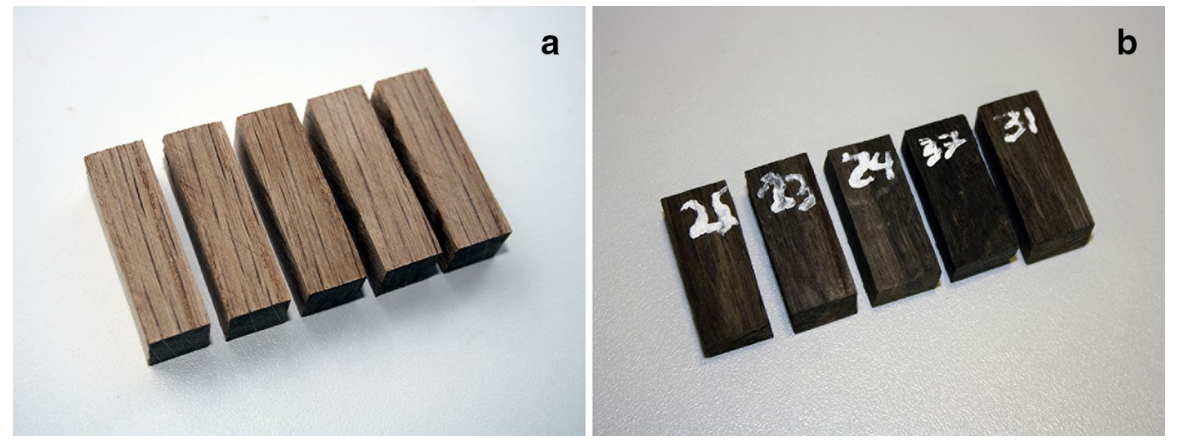

Fig. 1 Samples of a recent oak (SR); and b historical oak (SH) 
extract amount was then weighed. The following formula (1) was used to calculate the cyclohexane-ethanol extract:

$$
E(\%)=100 \times 5 \frac{(T 2-T 1)}{G \frac{(100-N)}{100}},
$$

where $T 1$ is the empty weight of the plastic tray; $T 2$ is the full weight of the plastic tray with dry extractives; $G$ is the weight of samples; and $N$ is the moisture content of samples. Analyses were run in triplicates.

\section{Holocellulose content}

After the extraction process described in chapter "Cyclohexane-ethanol extract," the wood samples were transferred into an Erlenmeyer flask. Subsequently, $80 \mathrm{~mL}$ of hot distilled water, $0.5 \mathrm{~mL}$ acetic acid $(96 \%)$, and $1 \mathrm{~g}$ of sodium chlorite were added. The mixture was heated in a water bath at $70{ }^{\circ} \mathrm{C}$ for $1 \mathrm{~h}$. After each succeeding hour, portions of $0.5 \mathrm{~mL}$ acetic acid and $1 \mathrm{~g}$ sodium chlorite were added by shaking. This process was repeated 6 times. After six cycles, the samples were left in the water bath overnight. At the end of $24 \mathrm{~h}$ of reaction, samples were cooled and filtered on a $G 1$ glass funnel filter and the holocellulose was washed with $10 \mathrm{~mL}$ acetone and water until the yellow color was removed (Rowell 2012). The prepared holocellulose was dried at $105{ }^{\circ} \mathrm{C}$ and then weighed. The following formula (2) was used to obtain the holocellulose content:

$$
H C(\%)=100 \times \frac{(S 2-S 1)}{G \frac{(100-N)}{100}}
$$

where $S 1$ is the empty filter funnel weight; $S 2$ is the full filter funnel weight; $G$ is the weight of samples; and $N$ is the moisture content of samples. Analyses were run in triplicates.

\section{a-Cellulose content}

The previously prepared holocellulose was transferred into a $250-\mathrm{mL}$ glass beaker, and $10 \mathrm{~mL}$ of $17.5 \% \mathrm{NaOH}$ solution was added. At 5-min intervals, portions of $5 \mathrm{~mL}$ $\mathrm{NaOH}$ solution were added until the holocellulose was fully covered with solution. The reaction time was $1 \mathrm{~h}$. The $\alpha$-cellulose was filtered on a $G 2$ porosity glass funnel filter and washed with $5 \% \mathrm{NaOH}$, acetic acid, and water. This washing cycle was repeated twice. The prepared $\alpha$-cellulose was dried at $105^{\circ} \mathrm{C}$ and then weighed (Rowell 2012). To calculate the $\alpha$-cellulose content, as in holocellulose, the following Eq. (3) was used:

$$
C \alpha(\%)=100 \times \frac{(S 2-S 1)}{G \frac{(100-N)}{100}},
$$


where $S 1$ is the empty filter funnel weight; $S 2$ is the full filter funnel weight; $G$ is the weight of wood samples; and $N$ is the moisture content of samples. Analyses were run in triplicates.

\section{Kürschner-Hoffer cellulose content}

In this research, the method of Kürschner and Hoffer (1929) was also used to obtain cellulose content as follows: Approximately, $1 \mathrm{~g}$ of the sample was refluxed with $100 \mathrm{~mL}$ nitric acid: ethanol 20:80 v/v mixture for $1 \mathrm{~h}$. After the removal of the reaction solution, the digestion was repeated with the same solvent mixture for $1 \mathrm{~h}$. The prepared Kürschner-Hoffer cellulose was filtered using a $G 2$ glass funnel filter and washed with $10 \mathrm{ml}$ ethanol and $500 \mathrm{~mL}$ hot distilled water. The following Eq. (4) was used to obtain the cellulose content:

$$
C(\%)=100 \times \frac{(S 2-S 1)}{G \frac{(100-N)}{100}},
$$

where $S 1$ is the empty filter funnel weight; $S 2$ is the full filter funnel weight; $G$ is the weight of wood samples; and $N$ is the moisture content of samples. Analyses were run in triplicates.

\section{Lignin content}

The total lignin content was estimated by the remaining fraction of the wood after ash content, holocellulose, and cyclohexane-ethanol extract content determinations by the use of the following formula (5):

$$
L=100-A_{d b}-H C-E
$$

where $A_{d b}$ is ash content, $H C$ is holocellulose content, and $E$ is cyclohexane-ethanol extract.

\section{Ash content}

To determine ash content, the standard EN 15403 (2011) was used. The same particle size as used in the chemical analyses was used here as well. The wood samples were dried in an oven, and about $2.5 \mathrm{~g}$ portions were transferred into pre-dried ceramic dishes. The dishes were placed in the cold furnace, and the furnace temperature was evenly raised to $(250 \pm 10){ }^{\circ} \mathrm{C}$ over a period of $50 \mathrm{~min}$. This temperature level was maintained for $60 \mathrm{~min}$ to allow the volatiles to leave the sample before ignition. The furnace temperature continued to be evenly raised to $(550 \pm 10){ }^{\circ} \mathrm{C}$ over a period of $60 \mathrm{~min}$, and this temperature level was maintained for $120 \mathrm{~min}$. The dishes and their contents were removed from the furnace and left to cool on a thick metal plate for $5 \mathrm{~min}$ to $10 \mathrm{~min}$ before being transferred to a desiccator without desiccant and allowed to cool to ambient temperature. After $30 \mathrm{~min}$, the cooled dishes were weighed. Equation (6) was used to calculate the ash content: 


$$
A_{d b}=\frac{\left(m_{3}-m_{1}\right)}{\left(m_{2}-m_{1}\right)} \times 100,
$$

where $m_{1}$ is the mass of the empty dish; $m_{2}$ is the mass of the dish plus the general analysis sample; and $m_{3}$ is the mass of the dish with the ash. Analyses were run in triplicates.

After the ash contents were obtained, SH ash and SR ash were placed into the scanning electron microscope (SEM) for imaging and to perform the subsequent elemental analysis by energy-dispersive X-ray (EDX) spectrometry.

\section{Characterization by scanning electron microscope (SEM)}

Wood samples and wood ash samples were both investigated. For wood samples, $10 \times 10 \times 10 \mathrm{~mm}^{3}$ sized specimens were used. The surface was cut with a razor blade before imaging. Some ash from SR and SH were placed inside the SEM specimen holder for the imaging of the ash samples. The surfaces/samples were not coated with a sputter coater before imaging. A Hitachi S-3400 N type equipment, using a vacuum of $70 \mathrm{~Pa}$ and an accelerating voltage of $10 \mathrm{kV}$, was used for SEM imaging.

\section{Energy-dispersive X-ray (EDX) spectrometry}

In this study, EDX spectrometry was used to identify the elements in the SH and SR samples. The point method was employed for the EDX analysis of both the wood and the ash samples. EDX analysis was completed equally at five samples of SR, $\mathrm{SH}, \mathrm{SR}$ ash and $\mathrm{SH}$ ash at five points on each, with the diameter of approximately three micrometers of each measurement point. The device used for SEM imaging was a Hitachi S-3400 N, equipped with a Bruker XFlash Detector 5010 EDX detector.

\section{Statistical analysis of the results}

For the comparison of samples, ANOVA analysis was run using Statistica 10 (StatSoft Inc., Tulsa, OK, USA) software at $p<0.05$ significance level, applying the Fischer LSD calculation method for post hoc test. To fulfill ANOVA analysis requirements, measurement values were first checked for normal distribution, and then, the variables were checked for the homogeneity of variances using Bartlett's $\chi^{2}$ test.

\section{Results and discussion}

\section{Chemical analysis}

Table 1 shows a summary of the results of the chemical analysis in SR and SH. As several different methods for cellulose determination from wood exist, and since none of these are perfect, the cellulose content was assayed using two different methods. The Kürschner and Hoffer (1929) method is based on refluxing 


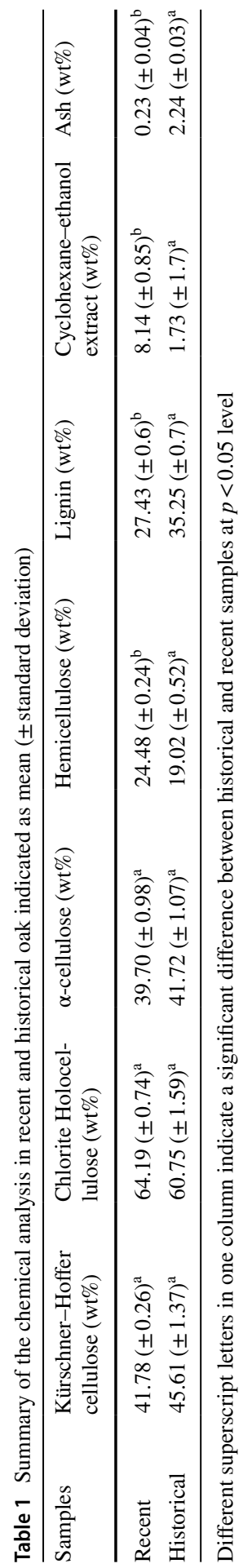


wood for $1 \mathrm{~h}$ with nitric acid: ethanol 20:80 v/v mixture. The assay is easy to execute and relatively fast; however, the prepared Kürschner-Hoffer cellulose may contain residues of hemicelluloses and the method often destroys some of the cellulose (Rowell 2012). The other method is the chlorite holocellulose assay combined with the subsequent $\alpha$-cellulose determination. The isolation of the chlorite holocellulose fraction is more time-consuming. Furthermore, applying too long of a reaction time may lead to excess chloriting and the loss of some of the polysaccharides (Rowell 2012). The different modifications of the chlorite assays are more readily used by researchers today for the determination of wood and fossil wood structural carbohydrate contents compared to the Kürschner-Hoffer assay.

According to Rowell (2012), the holocellulose content of Quercus species varies between 59 and $71 \%$ and can vary with age and location of the investigated tissue. Holocellulose content in historical oak wood was reported by Baar et al. (2019), 68.5-71.1\%. The $\alpha$-cellulose content for hardwoods reported by Pettersen (1984) was $45.4 \pm 3.5 \%$. According to the results, the difference in the amount of $\alpha$-cellulose in the SH and SR was not significant.

The results for Kürschner-Hoffer and $\alpha$-cellulose are in accordance as no significant differences were observed between SH and SR. Cellulose contents of 32.1-35.2\% (Kürschner-Hoffer method) for historical oak wood were reported by Krutul et al. (2010). These results confirm that other wood constituents were possibly changed during wood aging.

The hemicellulose content of the SH sample was significantly lower compared to the SR sample. Generally, this amount was $25 \%$ for hardwoods (Rowell 2012). According to Baar et al. (2019), the hemicellulose content for historical oak wood was $18.7-21.2 \%$. This result can be explained by the degradation of hemicelluloses as the second group of materials that are degraded during the aging of wood in soil contact (Rowell 2012). The amount of lignin in the SH and in the SR were both slightly higher than reported by Pettersen (1984), who found this amount for hardwoods to be $23 \pm 3 \%$. Compared to literature data, Baar et al. (2019) measured lignin contents in subfossil oak wood samples between 28.9 and $31.5 \%$, while Krutul et al. (2010) reported lignin content of fossil wood between 39.3 and $40.8 \%$. This increase in the lignin content can be attributed to the loss of wood compounds (e.g., the hemicelluloses), which causes the lignin content to increase relatively in SH compared to SR. The cyclohexane-ethanol extract of SH was significantly lower compared to the similar extract of SR. It can be concluded that this is due to the destruction and consecutive leaching of extractives in the first step of wood aging during soil contact (Pettersen 1984). The ash content in $\mathrm{SH}$ was $2.24 \%$, while in the SR it was only $0.23 \%$. The latter amount was consistent with the results of Pettersen (1984), who observed $0.5 \pm 0.3 \%$. According to Krutul et al. (2010), ash content in historical oak wood was $1.1-2.4 \%$. The significantly higher ash content of $\mathrm{SH}$ is due to the presence of inorganic depositions originating from the soil. This material is clearly visible in the SEM images as well as depositions in the cell lumens (Fig. 2b). 

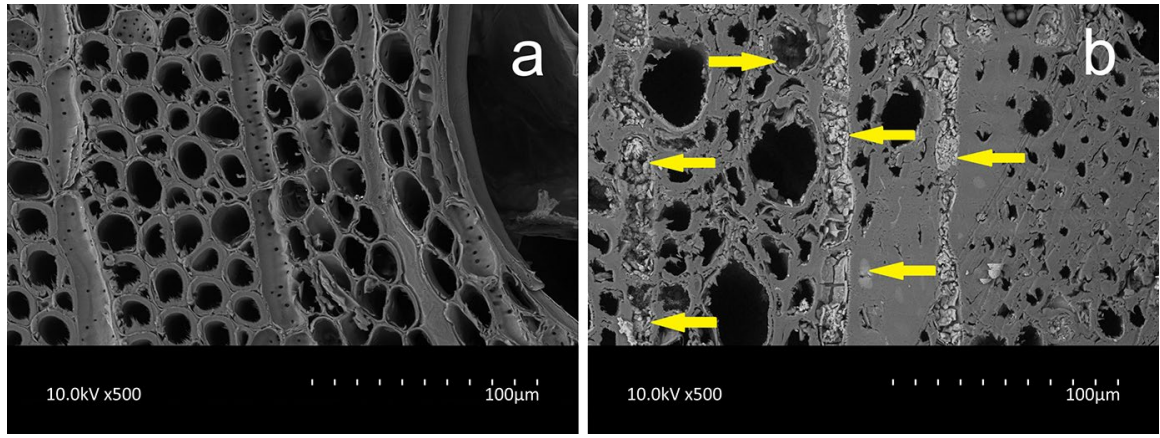

Fig. 2 SEM microphotograph with anatomical elements: a SR; b SH. Depositions in the lumens are marked with arrows

\section{Characterization by scanning electron microscope (SEM)}

Corroborating the analytical techniques of imaging and spectroscopy, wooden samples of SR and SH are discussed, followed by ash samples of SR and SH. The microscopic analysis evidenced no general deformation of anatomical characters (fiber, vessel, and ray cells). However, the sample surface was more brittle during preparation (cutting by razor blade). It is impossible to prepare clear surface cuts, which indicates cell wall degradation. The destruction can be attributed to the years spent underground, determined by the degradation of lignin and especially cellulose (as shown by the results in the chapter "Chemical analysis"), most likely caused by local environment factors such as bacteria, fungi, acid, and alkali (Bjurhager et al. 2012; Capano et al. 2015).

Since the SH had prolonged ground contact, the material within the soil entered the wood lumens (McClellan 2018). In addition to the differences in ash content and elemental composition caused by the long term soil contact, there were also visible differences between the SEM images of SH and SR samples. This difference is clearly seen as bright depositions in the cell lumens of SH (Fig. 2b), mainly in ray parenchyma cells, but partly in vessels, axial parenchyma, and fibers as well. The presence of deposited materials in the cell lumens of the SH samples is clearly visible. Such depositions are common in fossil wood, and they are identified as inorganic in origin (Krutul et al. 2010). In addition, the high amount of iron changed SH color, making it darker than normal (Pele et al. 2015). Wood blackening is caused by dissolved iron components in soil interacting with tannins found in oak. The strength of the materials' dark color is determined mainly by the period of wood deposition and the sediment conditions (Govorčin and Sinković 1995).

In addition to the SH and SR wood tissue images, SEM images of ash were taken. SEM images of SH and SR ash are shown in Fig. 3.

The structure of the ash samples showed remarkable differences during SEM imaging. According to Fig. 3b, which is related to the $\mathrm{SH}$ ash, the anatomical structure is well preserved and wood cell types can be identified. The reason for this was the presence of inorganic depositions, including iron in the structure of the SH (Pele 

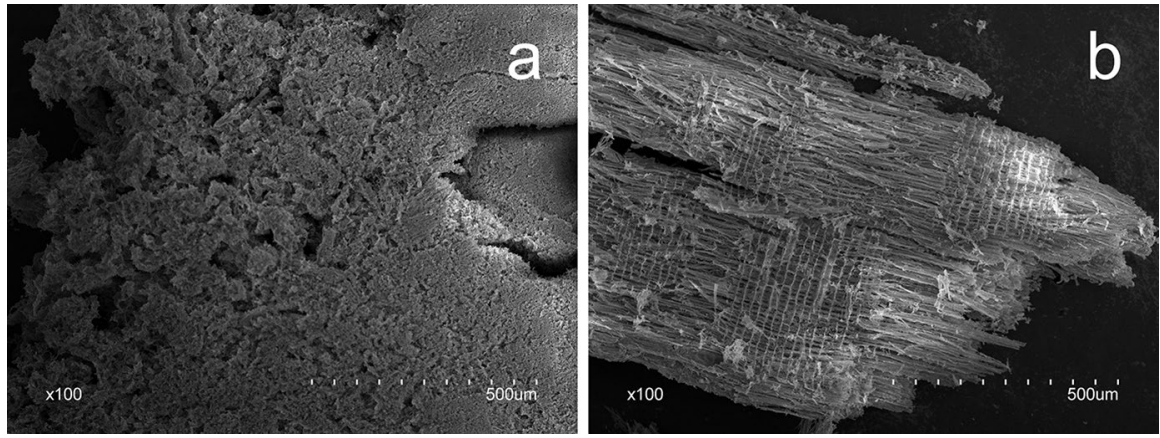

Fig. 3 SEM microphotograph of oak ash: a SR; b SH

et al. 2015). Unlike SH ash, SR ash was structureless, homogeneous, and porous. This is normal for all wood species. In addition to the differences in the structure of SH ash and SR ash, SH and SR differed in color. The high iron content within SH gives it a reddish color. Figure 4 shows this phenomenon, proving the presence of iron compounds that turn red when oxidized at high temperatures (Pele et al. 2015). EDX analysis proved the high ratio of iron in the historical samples as well.

\section{Energy-dispersive X-ray (EDX) spectrometry}

EDX spectrometry was used to identify the elements in the SH and SR samples. Table 2 lists the elemental composition in the SR, SH, and depositions in the SH.

According to the results, carbon and oxygen have the highest value in all three samples. No significant difference could be observed in the value of carbon in the three investigated samples. Bravo (2012) mentioned ranges in the amount of carbon between 41.08 and $47.75 \%$ for Quercus species. The reason for this difference can be due to the presence of other elements in the $\mathrm{SH}$ and amount of carbon in the deposited materials. Other elements in the SH include some usual soil elements. The presence of iron was especially noteworthy, as it was not detected
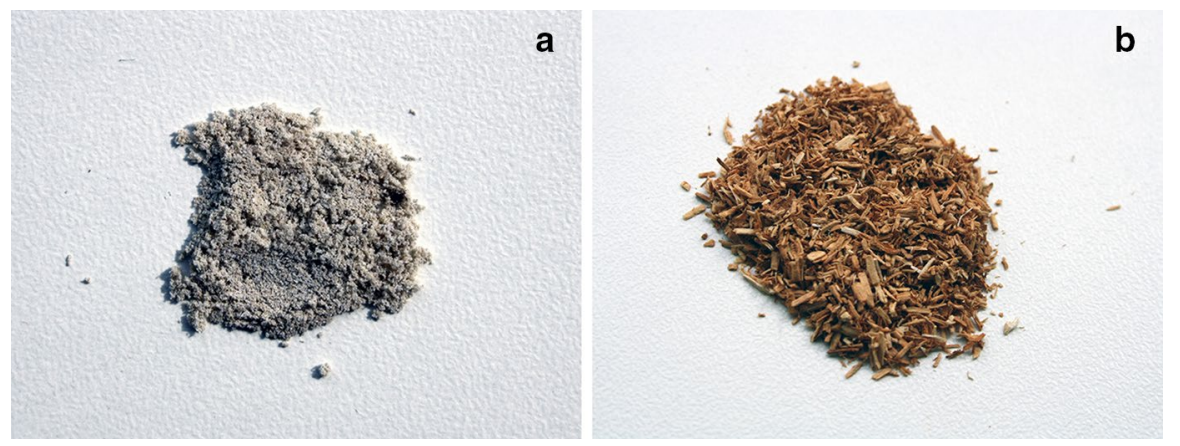

Fig. 4 Images of recent oak (SR) ash (a) and historical oak (SH) ash (b) 
Table 2 Elemental composition of the SR, SH, and depositions in the $\mathrm{SH}$

\begin{tabular}{llll}
\hline Element & SR $(\mathrm{wt} \%)$ & $\mathrm{SH}(\mathrm{wt} \%)$ & $\begin{array}{l}\text { Deposited materials inside } \\
\text { cell lumens of SH (wt } \%)\end{array}$ \\
\hline Carbon & $40.78( \pm 9.4)^{\mathrm{a}}$ & $34.81( \pm 3.34)^{\mathrm{a}}$ & $45.27( \pm 3.92)^{\mathrm{a}}$ \\
Sodium & $0.33( \pm 0.66)^{\mathrm{a}}$ & $0^{\mathrm{n} / \mathrm{a}}$ & $0.31( \pm 0.2)^{\mathrm{a}}$ \\
Chlorine & $0.19( \pm 0.38)^{\mathrm{a}}$ & $0^{\mathrm{n} / \mathrm{a}}$ & $0^{\mathrm{n} / \mathrm{a}}$ \\
Potassium & $0.32( \pm 0.48)^{\mathrm{a}}$ & $0^{\mathrm{n} / \mathrm{a}}$ & $1.22( \pm 0.46)^{\mathrm{b}}$ \\
Oxygen & $58.26( \pm 9.46)^{\mathrm{a}}$ & $51.20 \pm 1.6)^{\mathrm{b}}$ & $41.19( \pm 1.26)^{\mathrm{c}}$ \\
Calcium & $0.09( \pm 0.19)^{\mathrm{a}}$ & $1.21( \pm 1.07)^{\mathrm{a}}$ & $2.78( \pm 1.31)^{\mathrm{b}}$ \\
Magnesium & $0^{\mathrm{n} / \mathrm{a}}$ & $0.87( \pm 1.44)^{\mathrm{a}}$ & $1.11( \pm 0.36)^{\mathrm{a}}$ \\
Sulfur & $0^{\mathrm{n} / \mathrm{a}}$ & $0.74( \pm 0.5)^{\mathrm{b}}$ & $0.18( \pm 0.15)^{\mathrm{a}}$ \\
Iron & $0^{\mathrm{n} / \mathrm{a}}$ & $1.29( \pm 1.21)^{\mathrm{a}}$ & $7.86( \pm 3.11)^{\mathrm{b}}$ \\
Aluminum & $0^{\mathrm{n} / \mathrm{a}}$ & $0.69( \pm 0.77)^{\mathrm{b}}$ & $0.01( \pm 0.03)^{\mathrm{a}}$ \\
\hline
\end{tabular}

Data indicated as mean ( \pm standard deviation). Different superscript letters in a row indicate significant differences between samples at $p<0.05$ level

in the SR sample, yet showed high levels in SH and even higher levels in the SH lumen depositions. The reason for the black discoloration of SH was the presence of iron in the wood (Pele et al. 2015). Fossil oak wood contains higher amounts of iron, calcium, copper, zinc, and manganese than recent oak wood, according to Krutul and Kozakiewicz (2003). For example, iron and calcium contents in fossil oak wood equal $7350 \mathrm{mg} \mathrm{kg}^{-1}$ and $7800 \mathrm{mg} \mathrm{kg}^{-1}$, respectively, and corresponding values for recent oak wood were $120 \mathrm{mg} \mathrm{kg}^{-1}$ and $480 \mathrm{mg} \mathrm{kg}^{-1}$, respectively. In fossil wood $\left(25 \mathrm{mg} \mathrm{kg}^{-1}\right)$, the potassium concentration is much lower than in the recent wood $\left(1250 \mathrm{mg} \mathrm{kg}^{-1}\right)$.

Other elements such as calcium, potassium, magnesium, sulfur, and iron are the main elements of soil formation (Fenn 1982). These elements were found in the depositions in the $\mathrm{SH}$. The depositions contained iron, calcium, potassium, magnesium, and sulfur in descending order from 7.86 to $0.18 \%$.

Table 3 shows the elemental composition (wt\%) of the SR and SH ash obtained from the EDX analysis. Along with oxygen, the major components of wood ash are calcium, potassium, magnesium, silicon, and phosphorus (Nilsson and Timm 1983; Kofman 1987; Eriksson and Börjesson 1991; Holmroos 1993; Steenari et al. 1999).

According to the results, the sodium, magnesium, and iron contents of SH ash were significantly higher than in SR. The amount of sodium in SH ash was almost eight times higher compared to SR ash. The high amount of sodium in SH ash is probably the result of long-term soil contact (Pele et al. 2015). The amount of iron in $\mathrm{SH}$ ash was forty-five times higher and the amount of magnesium, seven times higher compared to SR ash. These considerable differences can be due to the deposition of elements from the soil into the wood material (McClellan 2018) as the SH was placed as a fence within soil. The amount of aluminum in the SH ash was more than three times higher than in SR ash. A possibility for this difference was the presence of aluminum-containing minerals (e.g., clay minerals) in the soil (Pele et al. 2015). 
Table 3 Elemental composition of the SR and $\mathrm{SH}$ ash (average \pm standard deviation)

\begin{tabular}{lcr}
\hline Element & SR $(\mathrm{wt} \%)$ & SH $(\mathrm{wt} \%)$ \\
\hline Oxygen & $46.58( \pm 5.5)^{\mathrm{a}}$ & $45.06( \pm 4.88)^{\mathrm{a}}$ \\
Sodium & $0.43( \pm 0.35)^{\mathrm{a}}$ & $3.36( \pm 0.92)^{\mathrm{b}}$ \\
Magnesium & $1.07( \pm 0.66)^{\mathrm{a}}$ & $7.57( \pm 1.56)^{\mathrm{b}}$ \\
Silicon & $1.26( \pm 0.56)^{\mathrm{a}}$ & $1.10( \pm 0.43)^{\mathrm{a}}$ \\
Phosphorus & $2.06( \pm 1.55)^{\mathrm{a}}$ & $0.16( \pm 0.09)^{\mathrm{b}}$ \\
Sulfur & $2.29( \pm 0.98)^{\mathrm{a}}$ & $2.33( \pm 1.38)^{\mathrm{a}}$ \\
Potassium & $22.66( \pm 5.3)^{\mathrm{a}}$ & $6.86( \pm 3.26)^{\mathrm{b}}$ \\
Calcium & $22.54( \pm 2.33)^{\mathrm{a}}$ & $19.49( \pm 5.21)^{\mathrm{a}}$ \\
Manganese & $0.69( \pm 0.48)^{\mathrm{a}}$ & $0.02( \pm 0.1)^{\mathrm{b}}$ \\
Iron & $0.31( \pm 0.48)^{\mathrm{a}}$ & $14.14( \pm 5.23)^{\mathrm{b}}$ \\
Aluminum & $0.04( \pm 0.13)^{\mathrm{a}}$ & $0.13( \pm 0.14)^{\mathrm{a}}$ \\
\hline
\end{tabular}

Different superscript letters in a row indicate significant differences between samples at $p<0.05$ level

The amount of potassium in the SR ash was more than three times higher than in $\mathrm{SH}$ ash. This might be due to potassium leaching from the wood material during the long-term soil contact. Soil has much lower potassium content than plants. Potassium and other water-soluble inorganic nutrients leach out with water in the soil. Consequently, as organic residues decompose, most of the potassium was quickly released. The behavior of potassium in the soil was determined more by physical than by chemical or biological processes (Fenn 1982). The amount of phosphorus in $\mathrm{SR}$ ash was almost thirteen times higher than in $\mathrm{SH}$ ash. The amount of manganese in SR ash was thirty-five times higher compared to SH ash. Possibly manganese was dissolved from the subfossil wood and absorbed by the soil. Other significant differences between the elemental composition of the SR and SH ash samples were not determined.

\section{Conclusion}

Oak wood is highly tolerant to the impact of biotic influences and is therefore frequently found in archaeological excavations. After lying in wet conditions for several years, the wood turns black as a consequence of reaction with iron compounds. Archaeological oak is an essential raw material. The research results from this study on recent oak wood (Quercus spp.) and historical oak wood show that the contents of cyclohexane-ethanol extract and hemicellulose in the recent oak wood are significantly higher than those of the historical oak, which was explained by the degradation of hemicelluloses and the leaching of native wood extractives during soil contact. The amount of lignin in the historical oak wood increased relatively compared to the recent oak wood; however, no significant difference was found between cellulose levels. Both Kürschner-Hoffer and chlorite holocellulose assays/ $\alpha$-cellulose assays proved to be suitable to assess the cellulose content of the samples. Data can 
be used as archaeometric characteristics of the samples. The ash content of the historical oak wood was remarkably higher, due to the deposition of inorganic elements from the soil into the wood. The amount of iron was remarkably higher in the historical oak wood due to the long-term soil contact of the oak material. This high amount of iron element in the historical oak wood caused the color change in the ash of the historical oak wood and possibly the color change of the historical oak wood material itself as well. Among inorganic components, higher amounts of calcium, magnesium, sulfur, iron, and aluminum were found in the historical wood. These above elements, as well as potassium, were found as deposition components in the cell lumens. These depositions were clearly visible in the SEM images as well. The amount of phosphorus, potassium, and manganese was lower in the ash of recent oak wood; however, other components displayed higher amounts.

Acknowledgements Open access funding provided by University of Sopron.

\section{Compliance with ethical standards}

Conflict of interest statement On behalf of all authors, the corresponding author states that no conflict of interest exists.

Open Access This article is licensed under a Creative Commons Attribution 4.0 International License, which permits use, sharing, adaptation, distribution and reproduction in any medium or format, as long as you give appropriate credit to the original author(s) and the source, provide a link to the Creative Commons licence, and indicate if changes were made. The images or other third party material in this article are included in the article's Creative Commons licence, unless indicated otherwise in a credit line to the material. If material is not included in the article's Creative Commons licence and your intended use is not permitted by statutory regulation or exceeds the permitted use, you will need to obtain permission directly from the copyright holder. To view a copy of this licence, visit http://creativecommons.org/licen ses/by/4.0/.

\section{References}

Baar J, Paschová Z, Hofmann T, Kolář T, Koch G, Saake B, Rademacher P (2019) Natural durability of subfossil oak: wood chemical composition changes through the ages. Holzforschung 74(1):47-59. https://doi.org/10.1515/hf-2018-0309

Bader TK, de Borst K, Fackler K, Ters T, Braovac S (2013) A nano to macroscale study on structure-mechanics relationships of archaeological oak. J Cultural Herit 14:377-388. https://doi. org/10.1016/j.culher.2012.09.007

Bjurhager I, Halonen H, Lindfors EL, Iversen T, Almkvist G, Gamstedt EK, Berglund LA (2012) State of degradation in archeological oak from the 17th century Vasa ship: substantial strength loss correlates with reduction in (holo)cellulose molecular weight. Biomacromolecules 13(8):2521-2527. https://doi.org/10.1021/bm3007456

Bravo CS (2012) Variation in carbon concentration and basic density along stems of sessile oak [Quercus petraea (Matt.) Liebl.] and Pyrenean oak (Quercus pyrenaica Willd.) in the Cantabrian Range (NW Spain). Ann For Sci 69(6):663-672. https://doi.org/10.1007/s13595-012-0183-6

Broda M, Popescu CM (2019) Natural decay of archaeological oak wood versus artificial degradation processes - An FT-IR spectroscopy and X-ray diffraction study. Spectrochim Acta Part A Mol Biomol Spectrosc 209:280-287. https://doi.org/10.1016/j.saa.2018.10.057

Capano M, Pignatelli O, Capretti C, Lazzeri S, Pizzo B, Marzaioli F, Martinelli N, Gennarelli I, Gigli S, Terrasi F, Macchioni M (2015) Anatomical and chemical analyses on wooden artifacts 
from a Samnite sanctuary in Hirpinia (Southern Italy). J Archaeol Sci 57:370-379. https://doi. org/10.1016/j.jas.2015.03.002

Carrión JS (2003) Plant evolution. (Evolución vegetal). Murcia: DM. 497 pp

Christiernin M, Notley SM, Zhang L, Nilsson T, Henriksson G (2009) Comparison between 10,000-year old and contemporary spruce lignin. Wood Sci Technol 43(1-2):23-41. https://doi.org/10.1007/ s00226-008-0222-5

EN 15403 (2011) Solid recovered fuels - Determination of ash content. European Committee for Standardization, Brussels

Eriksson J, Börjesson P (1991) Wood ash in forests. FUD-rapport. UB 1991/46, Vattenfall, Vällingby

Fengel D (1991) Aging and fossilization of wood and its components. Wood Sci Technol 46(1-3):153177. https://doi.org/10.1007/BF00223468

Fengel D, Wegener G (1989) Wood—chemistry, ultrastructure, reactions. Walter de Gruyter \& Co, Berlin, $\mathrm{p} 613$

Fenn LB (1982) Substitution of ammonium and potassium for added calcium in reduction of ammonia loss from surface-applied urea. Soil Sci Soc Am J 46:771

Florian MLE (1990) 1. Scope and history of archaeological wood. In: Rowell RM, Barbour RJ (eds) Archaeological wood: properties, chemistry, and preservation. Oxford University press, pp 3-32

Gelbrich J, Mai C, Militz H (2008) Chemical changes in wood degraded by bacteria. Int Biodeterior Biodegradation 61:24-32. https://doi.org/10.1016/j.ibiod.2007.06.007

Govorčin S, Sinković T (1995) Some physical and mechanical properties of the Bednja abonos. Drvna Industrija 46(1):9-14

Guo J, Xiao L, Han L, Wu H, Yang T, Wu S, Yin Y, Donaldson LA (2019) Deterioration of the cell wall in waterlogged wooden archeological artifacts, 2400 years old. Iawa J 40(4):1-25. https://doi. org/10.1163/22941932-40190241

Han L, Tian X, Keplinger T, Zhou H, Li R, Svedström K, Burgert I, Yin Y, Guo J (2020) Even visually intact cell walls in waterlogged archaeological wood are chemically deteriorated and mechanically fragile: a case of a 170 year-old shipwreck. Molecules 25(5):1113-1128. https://doi.org/10.3390/ molecules 25051113

Holmroos S (1993) Karaktärisering av vedaska [Characterization of wood ash]. VU-E 93: E64, Ekraftteknik VI-EC, Vattenfall Utveckling AB

Kofman P (1987) Wood-ashes from chip fueled heating plants: chemical composition, possibilities of application. The Danish Institute of Forest Technology, Hørsholm

Kolář T, Rybníček M, Střelcová M, Hedbávný J, Vít J (2014) The changes in chemical composition and properties of subfossil oak deposited in holocene sediments. Wood Res 59:146-166

Krutul D, Kocoń J (1982) Inorganic constituents and scanning electron microscopic study of fossil oak wood (Quercus sp.). Holzforschung Holzverwendung 34(5):69-77

Krutul D, Kozakiewicz P (2003) Impact of chemical factors on concentration changes of selected elements in native wood and excavated wood. Ann Warsaw Agric Univ-For Wood Technol 53:199-202

Krutul D, Radomski A, Zawadzki J, Zielenkiewicz T, Antczak A (2010) Comparison of the chemical composition of the fossil and recent oak wood. Wood Res 55:113-120

Kürschner K, Hoffer A (1929) Ein neues Verfahren zur Bestimmung der Cellulose in Hölzern und Zellstoffen [A new method for the determination of cellulose in wood and pulps]. Technol Chem Papier Zellstoff Fabr 26:125-129

Logan F (2003) The Vikings in history. Routledge, London and New York

Łucejko JJ, Zborowska M, Modugno F, Colombini MP, Pradzynski W (2012) Analytical pyrolysis versus classical wet chemical analysis to assess the decay of archaeological waterlogged wood. Anal Chim Acta 745:70-77. https://doi.org/10.1016/j.aca.2012.07.046

Luimes RA, Suiker ASJ, Verhoosel CV, Jorissen AJM, Schellen HL (2018) Fracture behaviour of historic and new oak wood. Wood Sci Technol 52(5):1243-1269. https://doi.org/10.1007/s0022 6-018-1038-6

Mańkowski P, Kozakiewicz P, Drożdżek M (2016) The selected properties of fossil oak wood from Medieval Burgh in Płońsk. Wood Res 61(2):287-298

Manning SW, Kromer B (2011) Radiocarbon dating archaeological samples in the Eastern Mediterranean, 1730 to $1480 \mathrm{BC}$ : further exploring the atmospheric radiocarbon calibration record and the archaeological implications. Archaeometry 53:413-439. https://doi.org/10.1111/j.1475-4754.2010.00556.x

McClellan T (2018) Soil composition. University of Hawaii-College of Tropical Agriculture and Human Resources 
Millard A (2002) A Bayesian approach to sapwood estimates and felling dates in dendrochronology. Archaeometry 44:137-143. https://doi.org/10.1111/1475-4754.00048

Moosavinejad SM, Madhoushi M, Vakili M, Rasouli D (2019) Evaluation of degradation in chemical compounds of wood in historical buildings using FT-IR and FT-Raman vibrational spectroscopy. Maderas. Ciencia y Tecnología 21(3):381-392. https://doi.org/10.4067/S0718-221X20190050003 10

Nilsson J, Timm B (1983) Environmental effects of wood and peat combustion. Summary and conclusions. Swedish National Environmental Protection Board, Solna

Passialis CN (1997) Physico-chemical characteristics of waterlogged archaeological wood. Holzforschung 51(2):111-113. https://doi.org/10.1515/hfsg.1997.51.2.111

Pele C, Guilminot E, Labroche S, Lemoine G, Baron G (2015) Iron removal from waterlogged wood: extraction by electrophoresis and chemical treatments. Stud Conserv 60(3):155-171. https://doi. org/10.1179/2047058413Y.0000000110

Pettersen RC (1984) The chemistry of solid wood, Advances in Chemistry Series 20, Chapter 2. Washington, DC

Pournou A (2008) Deterioration assessment of waterlogged archaeological lignocellulosic material via C-13 CP/MAS NMR. Archaeometry 50:129-141. https://doi.org/10.1111/j.1475-4754.2007.00343 $\mathrm{X}$

Richards JD (2005) The Vikings: a very short introduction. Oxford University Press, Jericho

Rowell RM (2012) Handbook of wood chemistry and wood composites, CRC Press

Sandu I, Hayashi M, Sandu ICA, Vasilache V, Stanciu C, Sandu AV (2007) Implication of the SEM-EDX technique in the study of old wood. Proceedings of the 2 nd international conference advanced technologies and materials-UGALMAT, vol II (ISSN 1843-5807), „Dunărea de Jos” University Press, Galaţi. 345-349

Scharnweber T, Couwenberg J, Heinrich I, Wilmking M (2015) New insights for the interpretation of ancient bog oak chronologies? Reactions of oak (Quercus robur L.) to a sudden peatland rewetting. Palaeogeogr Palaeoclimatol Palaeoecol 417:534-543. https://doi.org/10.1016/j.palaeo.2014.10.017

Sen A, Zhianski M, Glushkova M, Petkova K, Ferreira J, Pereira H (2016) Chemical composition and cellular structure of corks from Quercus suber trees planted in Bulgaria and Turkey. Wood Sci Technol 50(6):1261-1276. https://doi.org/10.1007/s00226-016-0836-y

Steenari BM, Karlsson LG, Lindqvist O (1999) Evaluation of the leaching characteristics of wood ash and the influence of ash agglomeration. Biomass Bioenergy 16(2):119-136. https://doi.org/10.1016/ S0961-9534(98)00070-1

Svedström K, Bjurhager I, Kallonen A, Peura M, Serimaa R (2012) Structure of oak wood from the Swedish warship Vasa revealed by X-ray scattering and microtomography. Holzforschung 66(3):355-363. https://doi.org/10.1515/hf.2011.157

Tegel W, Elburg R, Hakelberg D, Stäuble H, Büntgen U (2012) Early Neolithic water wells reveal the world's oldest wood architecture. PLoS ONE 7(12):e51374. https://doi.org/10.1371/journ al.pone.0051374

Todaro L, Zuccaro L, Marra M, Basso B, Scopa A (2012) Steaming effects on selected wood properties of Turkey oak by spectral analysis. Wood Sci Technol 46(1-3):89-100. https://doi.org/10.1007/ s00226-010-0377-8

Vasilache V, Sandu I, Luca C, Hayashi M, Sandu AV (2008) Determination of the conservation state of old wood artifacts. Proceedings of the 2 nd international conference advances materials and systems Icams, Ed. CERTEX (ISBN 978 - 973 - 1716 - 39 - 8), Bucureşti. 501 - 507

Walsh-Korb Z, Avérous L (2019) Recent developments in the conservation of materials properties of historical wood. Prog Mater Sci 102:167-221. https://doi.org/10.1016/j.pmatsci.2018.12.001

Publisher's Note Springer Nature remains neutral with regard to jurisdictional claims in published maps and institutional affiliations. 


\section{Affiliations}

\section{Amir Ghavidel ${ }^{1} \mathbb{D} \cdot$ Tamás Hofmann $^{2} \mathbb{D} \cdot$ Miklós Bak $^{3} \mathbb{D} \cdot$ Ion Sandu ${ }^{4}$.} Viorica Vasilache ${ }^{4}$

Amir Ghavidel

amir.ghavidelesfahlan@student.uaic.ro

Tamás Hofmann

hofmann.tamas@uni-sopron.hu

Ion Sandu

ion.sandu@uaic.ro

Viorica Vasilache

viorica_18v@yahoo.com

1 Doctoral School of Geosciences, Alexandru Ioan Cuza University of Iasi, Iasi, Romania

2 Institute of Chemistry, University of Sopron, Sopron, Hungary

3 Institute of Wood Science, University of Sopron, Sopron, Hungary

4 Institute of Interdisciplinary Research-Field Science, Alexandru Ioan Cuza University of Iasi, Iasi, Romania 